\title{
Baculovirus Expression Provides Direct Evidence for Heteromeric Assembly of $\mathrm{P}_{2} \mathrm{X}_{2}$ and $\mathrm{P}_{2} \mathrm{X}_{3}$ Receptors
}

\author{
Kathryn M. Radford, Caterina Virginio, Annmarie Surprenant, R. Alan North, and Eric Kawashima \\ Geneva Biomedical Research Institute, Glaxo Wellcome Research and Development, 1228 Geneva, Switzerland
}

$\mathrm{P} 2 \mathrm{X}_{2}$ and $\mathrm{P} 2 \mathrm{X}_{3}$ are subunits of $\mathrm{P} 2 \mathrm{X}$ receptors, cation channels opened by binding extracellular ATP. cDNAs encoding P2X and $\mathrm{P}_{2} \mathrm{X}_{3}$ receptor subunits, each with one of two C-terminal epitope tags, were cloned into baculovirus. Virally infected insect cells (Spodoptera frugiperda) expressed moderate to high levels of the corresponding proteins, as detected by Western blotting, by the specific binding of [ ${ }^{35}$ S]ATP and by wholecell recordings of membrane current evoked by ATP or $\alpha \beta$ methylene-ATP. In cells infected at the same time with two viruses encoding $\mathrm{P}_{2} \mathrm{X}_{2}$ and $\mathrm{P} 2 \mathrm{X}_{3}$ receptors, the two proteins could be cross-immunoprecipitated with antibodies specific for either of the epitope tags. Whole-cell recordings from these cells showed that ATP and $\alpha \beta$ methylene-ATP evoked currents with agonist sensitivity and desensitization quite distinct from those observed when $\mathrm{P}_{2} \mathrm{X}_{2}$ or $\mathrm{P}_{2} \mathrm{X}_{3}$ receptors were expressed alone. The results offer a method to express large amounts of $\mathrm{P} 2 \mathrm{X}$ receptor protein, and they provide direct evidence that $\mathrm{P} 2 \mathrm{X}_{2}$ and $\mathrm{P} 2 \mathrm{X}_{3}$ subunits assemble to form heteromeric channels having distinct properties from those formed as homomers.

Key words: ATP; P2X receptors; baculovirus; cation channels; coimmunoprecipitation; subunit assembly
$\mathrm{P} 2 \mathrm{X}$ receptors are membrane ion channels activated by extracellular ATP. Currently, seven subunits are known $\left(\mathrm{P}_{2} \mathrm{X}_{1}-\mathrm{P} 2 \mathrm{X}_{7}\right)$; each of these can form channels when expressed from the corresponding cDNA in cells such as Xenopus oocytes or human embryonic kidney (HEK) cells, although $\mathrm{P}_{2} \mathrm{X}_{5}$ and $\mathrm{P} 2 \mathrm{X}_{6}$ do so only poorly (Collo et al., 1996; North, 1996). It is assumed that, when heterologously expressed singly, these subunits assemble into channels as homo-oligomers. On the other hand, two lines of evidence suggest that, as for ligand-gated channels of the nicotinic and glutamate superfamilies (Barnard, 1996), native P2X receptors in cells also might form by the hetero-oligomerization of different subunits. The first kind of evidence is that the same cells often express more than one subunit mRNA. For example, throughout the nervous system and in some epithelial cells, the mRNAs for the $\mathrm{P} 2 \mathrm{X}_{4}$ and $\mathrm{P} 2 \mathrm{X}_{6}$ subunits have a widely overlapping distribution (Collo et al., 1996). A second finding that may suggest heteromultimeric channels is that the properties of the currents evoked by ATP in native cells do not always correspond to those observed when subunits are expressed singly in heterologous systems. One example is that rat $\mathrm{P} 2 \mathrm{X}_{4}$ and $\mathrm{P} 2 \mathrm{X}_{6}$ receptors are relatively insensitive to the commonly used $\mathrm{P} 2 \mathrm{X}$ receptor antagonists suramin and pyridoxal 5-phosphate-6-azophenyl2', $4^{\prime}$-disulphonic acid (PPADS), although responses to ATP recorded from central neurons that express this combination are blocked readily by these antagonists.

The further example in which the properties of native cells do not correspond well to those of any subunit expressed alone comes from sensory neurons. Many primary afferent neurons, including nodose ganglion cells (Khakh et al., 1995; Lewis et al., 1995) as well as some identified trigeminal ganglion nociceptors

\footnotetext{
Received April 18, 1996; revised June 9, 1997; accepted June 11, 1997.

We thank Dr. Anton Michel for his advice in establishing the $\left[{ }^{35} \mathrm{~S}\right] \mathrm{ATP} \gamma \mathrm{S}$ binding assay.

Correspondence should be addressed to Dr. K. M. Radford, Geneva Biomedical Research Institute, Glaxo Wellcome Research and Development, Plan-les-Ouates, 1228 Geneva, Switzerland.

Copyright (C) 1997 Society for Neuroscience $\quad 0270-6474 / 97 / 176529-05 \$ 05.00 / 0$
}

(Cook et al., 1997), respond both to ATP and its analog $\alpha \beta$ methylene-ATP ( $\alpha \beta$ meATP) with an inward current that desensitizes only minimally during a few seconds (see Surprenant et al., 1995). In contrast, in cells expressing cloned $\mathrm{P} 2 \mathrm{X}$ receptors, $\alpha \beta$ meATP either elicits strongly desensitizing currents $\left(\mathrm{P} 2 \mathrm{X}_{1}\right.$ or $\left.\mathrm{P} 2 \mathrm{X}_{3}\right)$ or has no effect $\left(\mathrm{P} 2 \mathrm{X}_{2}, \mathrm{P} 2 \mathrm{X}_{4}, \mathrm{P} 2 \mathrm{X}_{5}\right.$, and $\left.\mathrm{P} 2 \mathrm{X}_{6}\right)$. The nondesensitizing response to $\alpha \beta$ meATP observed in the sensory neurons can be reproduced in HEK 293 cells by coexpression of $\mathrm{P} 2 \mathrm{X}_{2}$ and $\mathrm{P} 2 \mathrm{X}_{3}$ receptor cDNAs; because this phenotype could not be accounted for readily by any simple mixing of channels with $\mathrm{P} 2 \mathrm{X}_{2}$ and $\mathrm{P} 2 \mathrm{X}_{3}$ properties, it was concluded that heteromeric channels must be formed (Lewis et al., 1995).

The main aim of the present experiments was to determine directly whether $\mathrm{P} 2 \mathrm{X}_{2}$ and $\mathrm{P} 2 \mathrm{X}_{3}$ receptor subunits could form a stable heteromeric complex. This was done by expressing the two cDNAs with distinct $\mathrm{C}$-terminal epitope tags that could be used for immunoprecipitation and detection. Baculovirus was used as the vector, and membrane expression of the channels after infection of insect cells was shown by radioligand binding and wholecell patch-clamp recording.

\section{MATERIALS AND METHODS}

Baculovirus construction and amplification. $\mathrm{P} 2 \mathrm{X}_{2}$ and $\mathrm{P} 2 \mathrm{X}_{3}$ receptor coding regions were each fused at the $\mathrm{C}$ terminal via linker DPGLN to either of two epitope tags [EE tag: EYMPME, Grussenmeyer et al. (1985); 179 tag: CLEPYTACD, Whitehorn et al. (1995)]. The resulting four cDNAs were cloned into pFastBac1 and transformed into DH10Bac-competent cells (Life Technologies, Grand Island, NY). Recombinant baculovirus subsequently was generated by homologous recombination via transfection of $1 \times 10^{6}$ insect cells with $5 \mu \mathrm{g}$ of each mini-prep recombinant bacmid DNA in the presence of $10 \mu \mathrm{g}$ of Cellfectin (Life Technologies) in $35 \mathrm{~mm}$ tissue culture plates (Nunc, Roskilde, Denmark). Virus was harvested after $72 \mathrm{hr}$ incubation at $27^{\circ} \mathrm{C}$ and amplified at a multiplicity of infection of $0.1 \mathrm{pfu} / \mathrm{cell}$ in suspension culture until virus titers approximating $10^{8} \mathrm{pfu} / \mathrm{ml}$ were obtained. Large-scale virus stocks were harvested after 1 week by centrifugation at $1000 \times g$ for $45 \mathrm{~min}$, and supernatants were stored at $4^{\circ} \mathrm{C}$. Virus titers were estimated by plaque assay (Knudson and Tinsley, 1974) and confirmed by 3-(4,5dimethylthiazol-2-yl)2,5-diphenyl-tetrazolium bromide (MTT) endpoint 
$\mathrm{P} 2 \mathrm{X}_{2}$
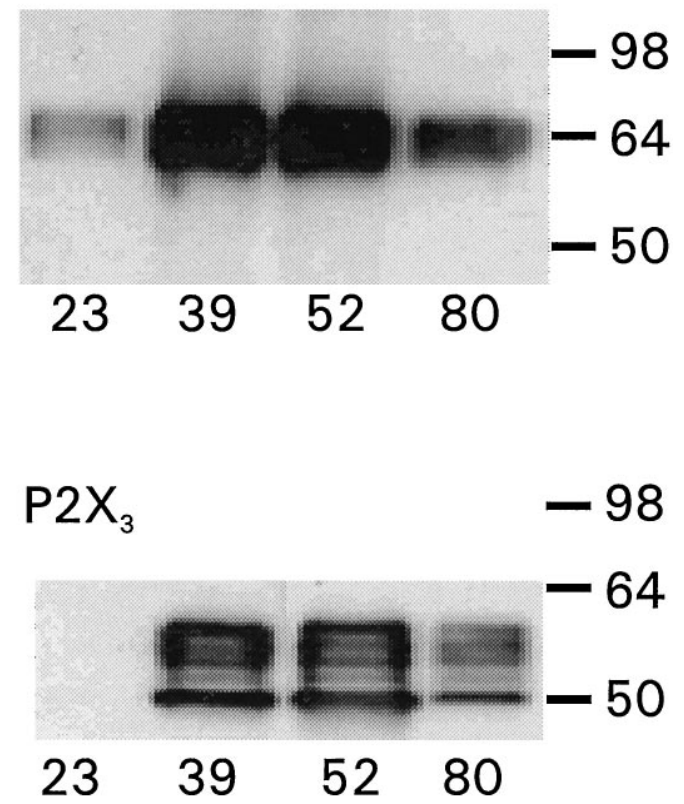

Figure 1. Time course of $\mathrm{P} 2 \mathrm{X}$ receptor expression by sf9 cells infected with baculovirus. Immunoblots detected epitope-tagged $\mathrm{P} 2 \mathrm{X}_{2}$ (anti-179; top) and $\mathrm{P} 2 \mathrm{X}_{3}$ (anti-EE; bottom) receptors at four times $(23,39,52$, and $80 \mathrm{hr})$ after infection. assay. For this assay, serial dilutions of virus $\left(10^{-5}\right.$ to $\left.10^{-10}\right)$ were made directly into insect cells suspensions $\left(8 \times 10^{5}\right.$ cells $\left./ \mathrm{ml}\right)$. Multiple repeats of $100 \mu \mathrm{l}$ aliquots were incubated at $27^{\circ} \mathrm{C}$ for $72 \mathrm{hr}$. MTT $(20 \mu \mathrm{l}$ of 7.5 $\mathrm{mg} / \mathrm{ml}$ ) was added to each well, and the cleavage of tetrazolium salt to formazan by noninfected proliferating cells allowed spectrophotometric detection of the viral endpoint. Virus titer and associated error were calculated from the endpoint, as described by Nielsen et al. (1992).

Cell culture and infection. Spodoptera frugiperda (sf9) insect cells (CRL-1711, American Type Culture Collection, Rockville, MD) were maintained in SF900II serum-free medium (Life Technologies) as $100 \mathrm{ml}$ suspension cultures in $250 \mathrm{ml}$ Erlenmeyer flasks (Schott, Mainz, Germany) and shaken at $150 \mathrm{rpm}$ on an orbital shaker at $27^{\circ} \mathrm{C}$. Cultures were grown until $2-3 \times 10^{6} \mathrm{cell} / \mathrm{ml}$ and subcultured at $3 \times 10^{5} \mathrm{cell} / \mathrm{ml}$. Cell density was determined with a hemocytometer; viability was assessed by exclusion of $0.2 \%$ trypan blue (Sigma, St. Louis, MO). Reported cell viability estimations represent the mean of triplicate estimations $\pm 95 \%$ confidence interval calculated from variances estimated via the method by Nielsen et al. (1991).

For infections, cultures were pooled at $1.5 \times 10^{6} \mathrm{cell} / \mathrm{ml}$, centrifuged at $1000 \times g$ for $5 \mathrm{~min}$, and resuspended in fresh medium. Resuspended cultures were inoculated at a multiplicity of $5 \mathrm{pfu} / \mathrm{cell}$ with baculovirus encoding $\mathrm{PX}_{2} 179, \mathrm{P} 2 \mathrm{X}_{3} \mathrm{EE}$, or $\mathrm{P} 2 \mathrm{X}_{2} 179$ and $\mathrm{P} 2 \mathrm{X}_{3} \mathrm{EE}$. A further uninfected culture was used as a control. Cultures were shaken at $200 \mathrm{rpm}$ at $27^{\circ} \mathrm{C}$ for $80 \mathrm{hr}$, and aliquots were removed at $0,23,39,52$, and $80 \mathrm{hr}$; these were were stored at $-80^{\circ} \mathrm{C}$.

Immunoprecipitation and Western blotting. Cells $\left(2 \times 10^{7}\right)$ were lysed on ice in $2 \mathrm{ml}$ of Tris-buffered saline [TBS; (in mM): 20 Tris, $150 \mathrm{NaCl}$, $1 \mathrm{CaCl}_{2}$, and $1 \mathrm{MgCl}_{2}$ ) with $1 \%$ Triton X-100 and homogenized (Polytron; twice for $10 \mathrm{sec}$ ). Lysate was centrifuged at $12,000 \times g$ for $10 \mathrm{~min}$ at $4^{\circ} \mathrm{C}$, and the supernatant was transferred to $200 \mu \mathrm{l}$ of a $1: 1$ mixture of washed protein A-agarose/protein G-agarose (Pharmacia, Uppsala, Sweden) for preadsorption of background proteins. Samples were rotated for $1 \mathrm{hr}$ at $4^{\circ} \mathrm{C}$, and beads were pelleted at $12,000 \times g$ for $3 \mathrm{~min}$. Supernatant $(800 \mu \mathrm{l})$ was rotated at $1 \mathrm{hr}$ at $4^{\circ} \mathrm{C}$ with either anti-EE or anti-179 antibodies $(25 \mu \mathrm{g} / \mathrm{ml}$ final concentration) and rotated overnight after the addition of $100 \mu \mathrm{l}$ of washed protein A-agarose/protein G. Beads were washed three times in lysis buffer by repeated centrifugation $(12,000 \times g$
A

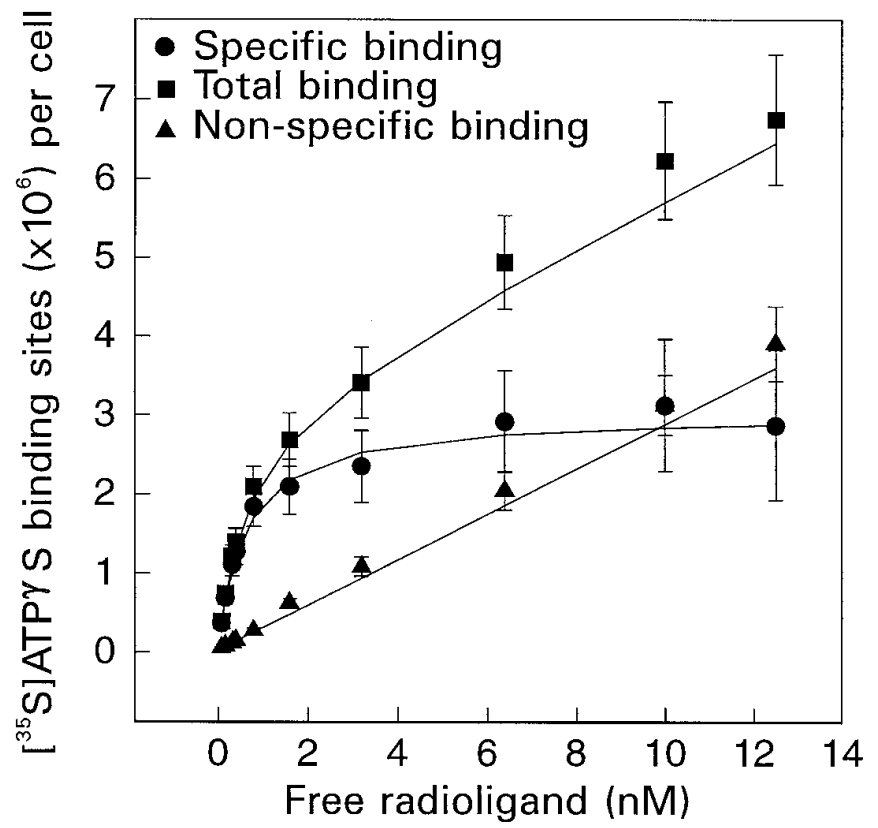

B

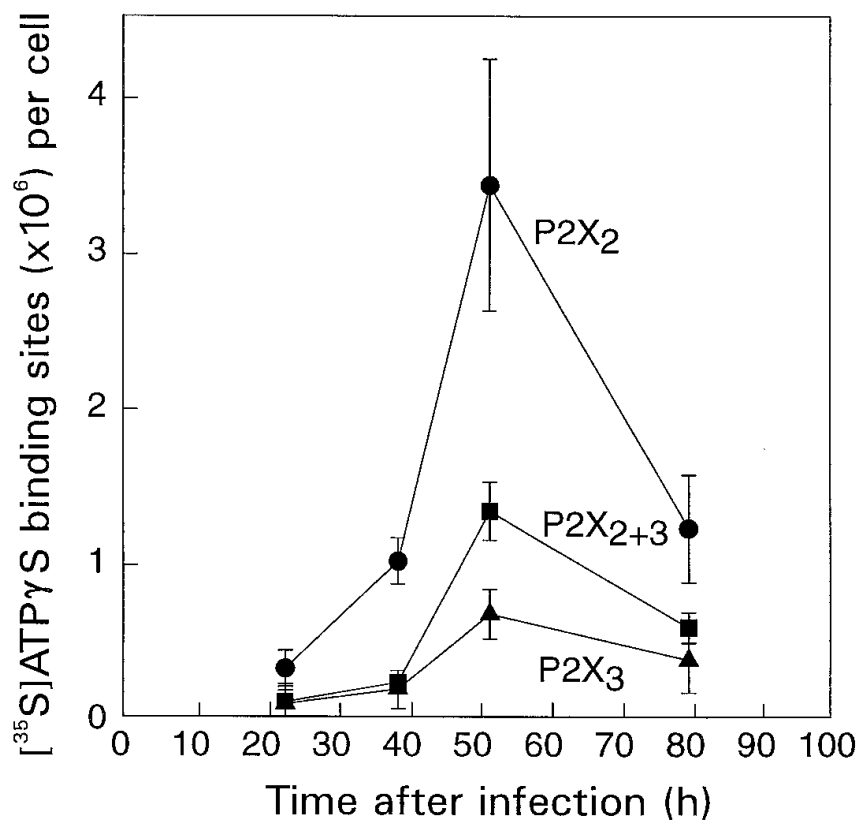

Figure 2. Binding of $\left[{ }^{35} \mathrm{~S}\right] \mathrm{ATP} \gamma \mathrm{S}$ to $\mathrm{sf} 9$ cells infected at $48 \mathrm{hr}(A)$ or at different times $(B)$ after infection with baculovirus encoding the $\mathrm{P} 2 \mathrm{X}_{2}$ receptor. $A$, The points for specific binding are fit to $B_{\max }[L]^{n} /\left([L]^{n}+K_{\mathrm{D}}{ }^{n}\right)$, where $[L]$ is the free $\left[{ }^{35} \mathrm{~S}\right] \mathrm{ATP} \gamma \mathrm{S}$ concentration; they provide estimates for $B_{\text {max }}$ of $2.8 \times 10^{6}$ binding sites per cell and $K_{\mathrm{D}}$ of $0.63 \mathrm{nM}$. The points are the means of triplicates from two experiments, and error bars indicate $95 \%$ confidence limits from Student's $t$ distribution. $B$, The number of binding sites per cell was greater for $\mathrm{P} 2 \mathrm{X}_{2}$ than for $\mathrm{P} 2 \mathrm{X}_{3}$ or $\mathrm{P} 2 \mathrm{X}_{2}$ plus $\mathrm{P} 2 \mathrm{X}_{3}$. In each case this was maximal at $52 \mathrm{hr}$. 
for $3 \mathrm{~min})$ and rotation $\left(4^{\circ} \mathrm{C}\right.$ for $\left.10 \mathrm{~min}\right)$. Each pellet was resuspended in $50 \mu \mathrm{l}$ of sample buffer and boiled for $5 \mathrm{~min}$; after $1 \mathrm{~min}$ of centrif ugation $10 \mu \mathrm{l}$ was run on $12 \%$ Tris-glycine gels (Novex, San Diego, CA). Samples immunoprecipitated with anti-EE or anti-179 antibody were detected by Western blot/ECL format (Amersham, Braunschweig, Germany), using the anti-179 or anti-EE antibody, respectively, as the primary antibody and anti-mouse IgG as the secondary antibody. In some experiments lysates of cells expressing $\mathrm{P} 2 \mathrm{X}_{2}$ receptors were treated with Endo $\mathrm{H}$ (Boehringer Mannheim, Mannheim, Germany) $(50 \mathrm{mU} / \mathrm{ml}$, overnight at $\left.4^{\circ} \mathrm{C}\right)$.

$\left[{ }^{35} S\right] A T P \gamma S$ binding. The ligand binding assay was similar to that described by Michel et al. (1996a,b), modified by the use of multiscreen membrane plates $(0.65 \mu \mathrm{m}$ pore size; Millipore, Bedford, MA) to separate bound from unbound radioligand. Intact insect cells infected with $\mathrm{P} 2 \mathrm{X}_{2}$ or $\mathrm{P} 2 \mathrm{X}_{3}$ receptor baculovirus $\left(5 \times 10^{4} /\right.$ well $)$ were incubated for $2-3$ $\mathrm{hr}$ at $4{ }^{\circ} \mathrm{C}$ with $\left[{ }^{35} \mathrm{~S}\right] \mathrm{ATP} \gamma \mathrm{S}$ in $50 \mathrm{~mm}$ Tris-HCl, pH 7.1, plus $1 \mathrm{~mm}$ EDTA. This buffer, with $2 \mu \mathrm{g} / \mathrm{ml}$ aprotinin, $2 \mu \mathrm{g} / \mathrm{ml}$ leupeptin, $100 \mu \mathrm{g} / \mathrm{ml}$ phenylmethylsulfonyl fluoride, and $50 \mu \mathrm{g} / \mathrm{ml} N^{\alpha}$-tosyl-Lys chloromethyl ketone, also was used for sample and reagent dilution and plate washing. Unbound radioligand was washed from plates by vacuum filtration $(3 \times$ $250 \mu \mathrm{l} /$ well), and plates were counted in a Wallac scintillator after the addition of $30 \mu \mathrm{l}$ of scintillation fluid. For time course measurements, a single concentration of $\left[{ }^{35} \mathrm{~S}\right] \mathrm{ATP} \gamma \mathrm{S}$ was used, which was close to the $K_{\mathrm{D}}$ $(0.4 \mathrm{nM})$, and binding was measured at $23,39,52$, and $80 \mathrm{hr}$ postinfection. Nonspecific binding was defined by using $15 \mu \mathrm{M}$ 2-methylthio-ATP; the total binding of $\left[{ }^{35} \mathrm{~S}\right] \mathrm{ATP} \gamma \mathrm{S}$ observed in the presence of $15 \mu \mathrm{M}$ 2-methylthio-ATP was the same for infected and noninfected cells.

Electrophysiology. At $\sim 30$ or $52 \mathrm{hr}$ after infection, cells were transferred from the culture to coverslips and allowed to attach for $1-2 \mathrm{hr}$ at $27^{\circ} \mathrm{C}$. Whole-cell recordings were obtained with glass pipettes $(4-6 \mathrm{M} \Omega)$ containing (in mM): $140 \mathrm{CsCl}, 11$ EGTA, and $10 \mathrm{HEPES}$. The external solution contained (in mM): $147 \mathrm{NaCl}, 2 \mathrm{KCl}, 2 \mathrm{CaCl}_{2}, 1 \mathrm{MgCl}_{2}, 12$ glucose, and 10 HEPES. Agonists were applied by U-tube delivery system (Evans et al., 1995). Responses were obtained by applying agonist for $1 \mathrm{sec}$ at intervals of 2 min $\left(\mathrm{P} 2 \mathrm{X}_{2} ; \mathrm{P} 2 \mathrm{X}_{2}\right.$ and $\left.\mathrm{P} 2 \mathrm{X}_{3}\right)$ and 4 min $\left(\mathrm{P} 2 \mathrm{X}_{3}\right)$.

\section{RESULTS}

\section{Time course of $\mathbf{P} 2 \mathrm{X}$ receptor protein expression}

$\mathrm{P} 2 \mathrm{X}$ receptor subunit expression was monitored by antibodyspecific protein production (Fig. 1). This was detectable but very weak at $23 \mathrm{hr}$ after infection and much stronger at 39 and $52 \mathrm{hr}$. Both the $\mathrm{P} 2 \mathrm{X}_{2}$ and the $\mathrm{P} 2 \mathrm{X}_{3}$ receptors migrated as several closely spaced bands, with molecular weights of $\sim 64$ and $50 \mathrm{kDa}$, respectively (Fig. 1). We assume that these represent differently glycosylated forms: treatment of the $\mathrm{P} 2 \mathrm{X}_{2}$ receptor-infected cells with Endo $\mathrm{H}$ eliminated the higher molecular weight bands (data not shown). For both subtypes, some antibody-positive material disappeared between 52 and $80 \mathrm{hr}$ after infection; bands at lower molecular weight that might result from degradation were not detected in either case. In cultures expressing the $\mathrm{P} 2 \mathrm{X}_{2}$ receptor, the fraction of cells excluding trypan blue, a measure of cell lysis, fell from $97.5 \pm 9.5 \%$ at time 0 , to $93.5 \pm 9.7 \%$ at $23 \mathrm{hr}, 83.5 \pm$ $7.9 \%$ at $39 \mathrm{hr}, 52.5 \pm 5.4 \%$ at $52 \mathrm{hr}$, and $6 \pm 0.9 \%$ at $80 \mathrm{hr}(n=$ $6)$. The $\mathrm{P} 2 \mathrm{X}$ receptor expression and lysis kinetics for the $\mathrm{P} 2 \mathrm{X}_{3}$ receptor-infected and coinfected cultures were not significantly different from those observed with $\mathrm{P} 2 \mathrm{X}_{2}$ alone.

\section{Binding of $\left[{ }^{35} \mathrm{~S}\right] \mathrm{ATP} \gamma \mathrm{S}$}

The specific binding of $\left[{ }^{35} \mathrm{~S}\right] \mathrm{ATP} \gamma \mathrm{S}$ to cells infected with $\mathrm{P} 2 \mathrm{X}_{2}$ receptor constructs was well fit by a simple adsorption isotherm when it was measured $48 \mathrm{hr}$ after infection (Fig. 2). From the direct fit of a hyperbola to the data, the $K_{\mathrm{D}}$ was $0.6 \mathrm{~nm}$, and the $B_{\text {max }}$ corresponded to $3 \times 10^{6}$ binding sites per cell. Saturation analysis also was performed for cells expressing $\mathrm{P} 2 \mathrm{X}_{3}$, and both receptors and the $K_{\mathrm{D}}$ estimates were not significantly different $\left(\mathrm{P} 2 \mathrm{X}_{2}, 0.63 \pm 0.08 \mathrm{~nm} ; \mathrm{P}_{2} \mathrm{X}_{3}, 0.54 \pm 0.06 \mathrm{~nm} ; \mathrm{P}_{2} \mathrm{X}_{2}\right.$ and $\mathrm{P} 2 \mathrm{X}_{3}$, $0.57 \pm 0.09 \mathrm{~nm} ; n=3)$. These values are similar to those described for $\mathrm{P} 2 \mathrm{X}_{2}$ and $\mathrm{P} 2 \mathrm{X}_{3}$ expressed in other systems (Michel
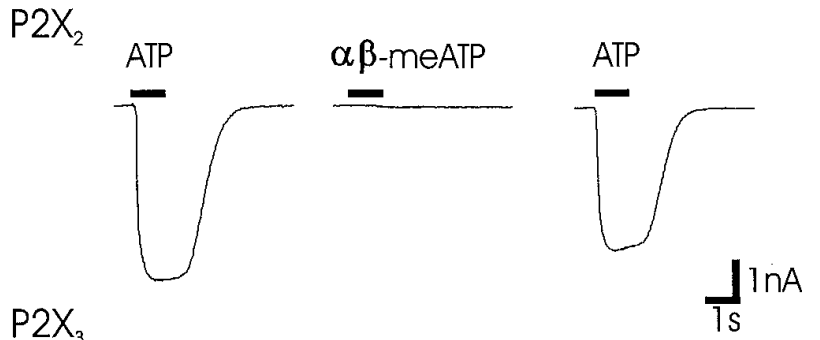

$\mathrm{P} 2 \mathrm{X}_{3}$
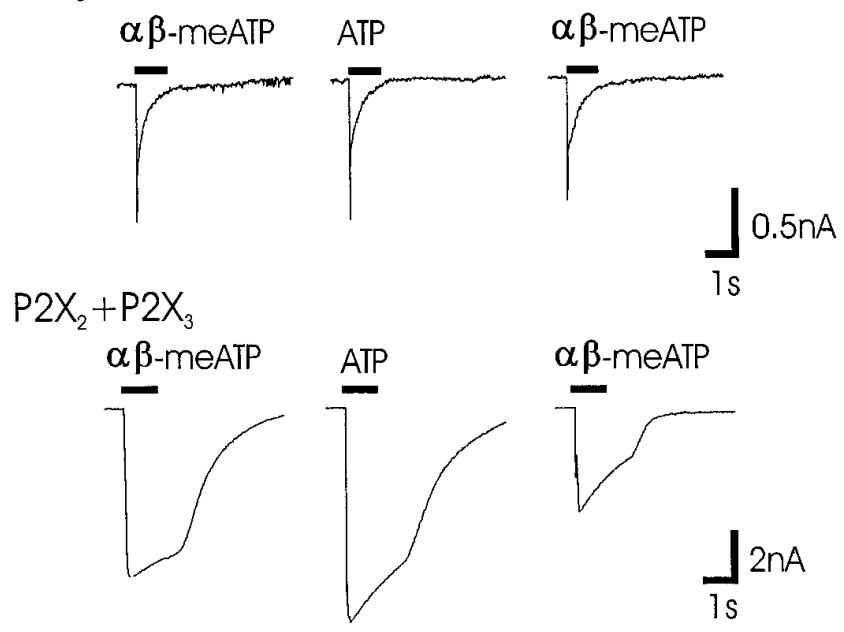

Figure 3. Membrane currents evoked by ATP and $\alpha \beta$ meATP recorded in sf9 cells infected with baculovirus encoding $\mathrm{P} 2 \mathrm{X}_{2}, \mathrm{P} 2 \mathrm{X}_{3}$, or $\mathrm{P} 2 \mathrm{X}_{2}$ and $\mathrm{P}_{2} \mathrm{X}_{3}$ receptors. Solid lines above traces indicate period of application of agonist. Top, Cells expressing $\mathrm{P}_{2} \mathrm{X}_{2}$ receptors responded to ATP $(30 \mu \mathrm{M})$, but not to $\alpha \beta$ meATP $(30 \mu \mathrm{M})$; the current showed little desensitization. All three traces were taken in order from the same cell; the second application of ATP was $8 \mathrm{~min}$ after the first. Recordings were made $30 \mathrm{hr}$ after infection. Middle, Cells expressing $\mathrm{P}_{2} \mathrm{X}_{3}$ receptors responded both to $\operatorname{ATP}(30 \mu \mathrm{M})$ and to $\alpha \beta$ meATP $(30 \mu \mathrm{M})$; the current desensitized almost fully within the period of application $(1 \mathrm{sec})$. Recordings were made $50 \mathrm{hr}$ after infection and $2 \mathrm{hr}$ after adding apyrase $(30 \mathrm{U} / \mathrm{ml})$. Bottom, Cells coinfected with baculovirus encoding $\mathrm{P} 2 \mathrm{X}_{2}$ and $\mathrm{P} 2 \mathrm{X}_{3}$ receptors responded both to ATP $(30 \mu \mathrm{M})$ and to $\alpha \beta$ meATP $(30 \mu \mathrm{M})$, but in this case the current desensitized much more slowly. Recordings were made $50 \mathrm{hr}$ after infection.

et al., 1996a,b; Miller et al., 1996); in subsequent experiments a single concentration of $\left[{ }^{35} \mathrm{~S}\right] \mathrm{ATP} \gamma \mathrm{S}$ was used $(0.4 \mathrm{nM})$ with or without $15 \mu \mathrm{M}$ 2MeSATP. For $\mathrm{P}_{2} \mathrm{X}_{2}$ receptors, the number of specific binding sites was $3.4 \pm 0.8 \times 10^{6} /$ cell at $52 \mathrm{hr}$ and $1.2 \pm$ $0.3 \times 10^{6} /$ cell at $80 \mathrm{hr}$; the corresponding values for cells infected with $\mathrm{P} 2 \mathrm{X}_{3}$ receptors were $6.6 \pm 1.6 \times 10^{5} /$ cell at $52 \mathrm{hr}$ and $3.7 \pm$ $2.1 \times 10^{5} /$ cell at $80 \mathrm{hr}$; for cells infected with $\mathrm{P}_{2} \mathrm{X}_{2}$ and $\mathrm{P} 2 \mathrm{X}_{3}$ receptors, they were $1.3 \pm 0.2 \times 10^{6} /$ cell at $52 \mathrm{hr}$ and $5.8 \pm 1.0 \times$ $10^{5} /$ cell at $80 \mathrm{hr}(n=3$ in each case $)$. The decline between 52 and $80 \mathrm{hr}$ correlates well with the results of immunoblotting (Fig. 1).

\section{ATP-induced currents in infected sf9 cells}

ATP $(30 \mu \mathrm{M})$ applied for $1-2$ sec evoked a sustained current in cells infected with $\mathrm{P}_{2} \mathrm{X}_{2}$ receptors, whereas $\alpha \beta$ meATP $(30 \mu \mathrm{M})$ had no effect ( $n=2$; Fig. 3$)$. The current evoked by ATP $(30 \mu \mathrm{M})$ was $4.5 \pm 0.6 \mathrm{nA}(n=6)$ at $30 \mathrm{hr}$ after infection, $1.3 \pm 0.4 \mathrm{nA}$ $(n=4)$ at $40 \mathrm{hr}$, and $1.5 \pm 0.4 \mathrm{nA}(n=4)$ at $48 \mathrm{hr}$. In cells expressing $\mathrm{P} 2 \mathrm{X}_{3}$ receptors, $\alpha \beta$ meATP $(30 \mu \mathrm{M})$ evoked a rapidly desensitizing current in four of five cells tested $(1.5 \pm 0.3 \mathrm{nA}, n=$ 4; $50 \mathrm{hr}$ after infection; Fig. 3). However, this was seen only after pretreatment of cells with apyrase $(30 \mathrm{U} / \mathrm{ml}$ for $2 \mathrm{hr}) ; \alpha \beta$ meATP $(30 \mu \mathrm{M})$ had no effect in five other cells infected with $\mathrm{P}_{2} \mathrm{X}_{3}$ 


\begin{tabular}{|c|c|c|c|c|c|c|c|c|}
\hline \multirow{2}{*}{$\begin{array}{l}\text { infected } \\
\text { with } \\
\text { immunoprecipitated } \\
\text { with }\end{array}$} & \multicolumn{2}{|c|}{$P 2 X_{2}-179$} & \multicolumn{2}{|c|}{$\begin{array}{c}\mathrm{P} 2 \mathrm{X}_{2}-179 \\
\text { and } \mathrm{P} 2 \mathrm{X}_{3}-\mathrm{EE}\end{array}$} & \multicolumn{2}{|c|}{ P2X3-EE } & \multicolumn{2}{|c|}{$\begin{array}{c}P 2 X_{2}-179 \\
\text { and } P 2 X_{3}-E E\end{array}$} \\
\hline & anti-179 & anti-EE & anti-EE & anti-179 & anti-EE & anti-179 & anti-EE & anti-179 \\
\hline $\begin{array}{l}\text { detected } \\
\text { with }\end{array}$ & anti-179 & anti-179 & anti-179 & anti-179 & anti-EE & anti-EE & anti-EE & anti-EE \\
\hline
\end{tabular}
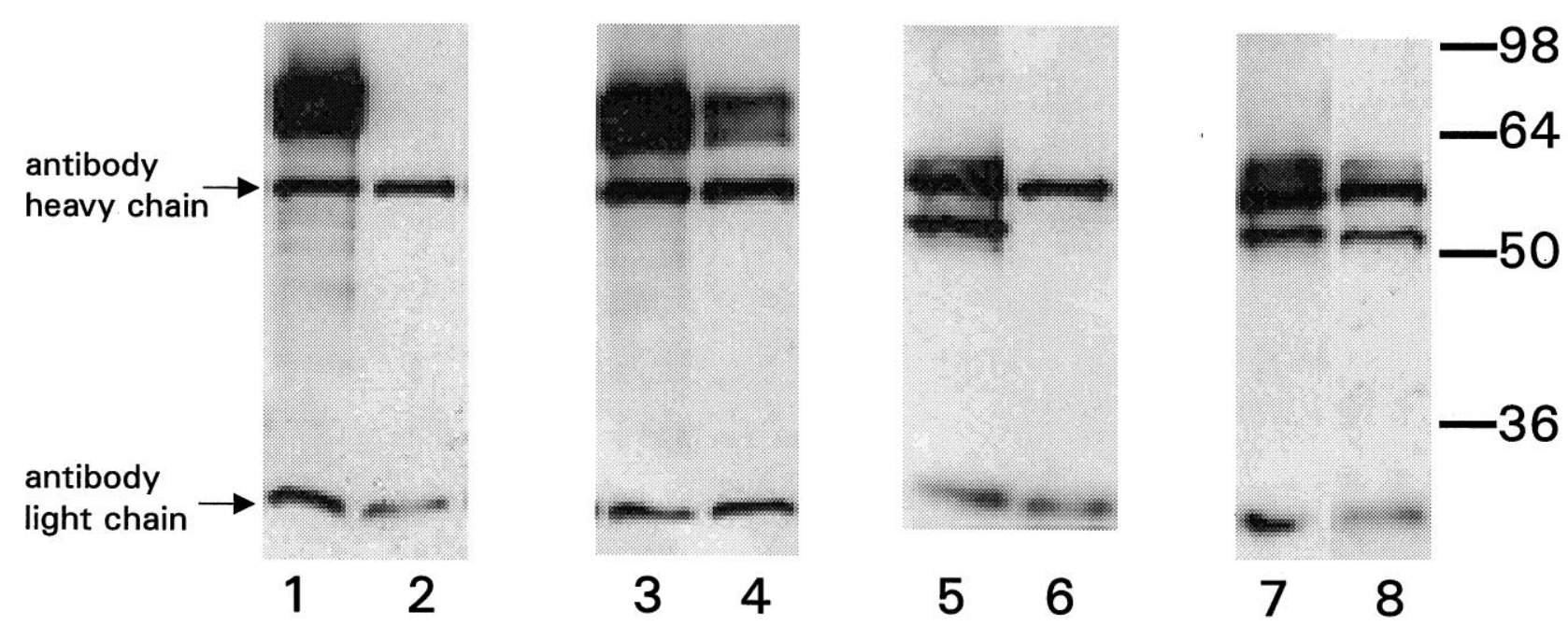

Figure 4. Coimmunoprecipitation of $\mathrm{P} 2 \mathrm{X}_{2}$ and $\mathrm{P} 2 \mathrm{X}_{3}$ subunits. Cells were infected with baculovirus encoding epitope-tagged $\mathrm{P} 2 \mathrm{X}_{2}$ receptors $\left(P 2 X_{2} 179\right)$, $\mathrm{P}_{2} \mathrm{X}_{3}$ receptors $\left(P 2 X_{3} E E\right)$, or both receptors. Cells were harvested at $52 \mathrm{hr}$ and solubilized with $1 \%$ Triton X-100; the supernatant was immunoprecipitated with either antibody, as indicated. Then either antibody was used to identify the proteins in the immunoprecipitate. The antibody heavy chain lies within the $\mathrm{P} 2 \mathrm{X}_{3}$ bands.

receptor baculovirus, which were not treated with apyrase. This result is similar to that observed for HL60 cells (which express $\mathrm{P} 2 \mathrm{X}_{1}$ receptors), in which chronic desensitization by ATP released from the cells prevents any current being elicited by ATP unless apyrase is applied first (Buell et al., 1996). Cells infected with both the $\mathrm{P} 2 \mathrm{X}_{2}$ and $\mathrm{P} 2 \mathrm{X}_{3}$ baculovirus responded to ATP (30 $\mu \mathrm{M} ; 4.7 \pm 2.7 \mathrm{nA} ; n=2)$ and $\alpha \beta \mathrm{meATP}(30 \mu \mathrm{M} ; 5.9 \pm 2.9 \mathrm{nA}$; $n=2$ ) with a sustained current (Fig. 3; tested $30 \mathrm{hr}$ after infection); this was similar to that previously observed for HEK cells transfected with both receptor cDNAs (Lewis et al., 1995).

\section{Coimmunoprecipitation of $\mathbf{P} 2 X_{2}$ and $P 2 X_{3}$ subunits}

Insect cells infected with $\mathrm{P} 2 \mathrm{X}_{2} 179, \mathrm{P} 2 \mathrm{X}_{3} \mathrm{EE}$, or both receptors were harvested after $52 \mathrm{hr}$ and solubilized with Triton X-100; then the supernatant was immunoprecipitated with anti-179 or anti-EE antibodies. $\mathrm{P}_{2} \mathrm{X}_{2} 179$ receptors could be immunoprecipitated with anti-179, but not with anti-EE (Fig. 4, lanes 1 and 2). $\mathrm{P} 2 \mathrm{X}_{3} \mathrm{EE}$ receptors could be immunoprecipitated with anti-EE, but not with anti-179 (Fig. 4, lanes 5 and 6). In cells coinfected with both $\mathrm{P}_{2} \mathrm{X}_{2} 179$ and $\mathrm{P} 2 \mathrm{X}_{3} \mathrm{EE}$, the material immunoprecipitated by anti-179 or anti-EE could be detected with either anti179 (Fig. 4, lanes 3 and 4) or anti-EE (Fig. 4, lanes 7 and 8). In each case the immunoprecipitated material corresponded in size to the cognate receptor; $\mathrm{P} 2 \mathrm{X}_{2} 179$ ran as a broad smear of $\sim 64$ $\mathrm{kDa}$, and $\mathrm{P} 2 \mathrm{X}_{3} \mathrm{EE}$ ran as a series of bands, of which the smallest was $\sim 50 \mathrm{kDa}$ (Fig. 4).

\section{DISCUSSION}

The main result of the present work is that $\mathrm{P} 2 \mathrm{X}_{2}$ and $\mathrm{P} 2 \mathrm{X}_{3}$ receptors express robustly in sf9 cells infected with baculovirus constructs, which encode them, and that they can be coimmunoprecipitated. Receptor expression was determined in three ways. Epitope tags presumably would detect individual subunits whether or not in the plasma membrane. Binding of $\left[{ }^{35} \mathrm{~S}\right] \mathrm{ATP} \gamma \mathrm{S}$ would detect subunits or, presumably, multimeric forms in the plasma membrane; however, at later times postinfection this would include intracellular membranes from cells undergoing lysis. Electrophysiological recording detects functioning multimeric receptors in the membrane of intact cells.

The time course of appearance of P2X receptor protein was consistent with what is known about the progress of infection of baculovirus in insect cells (O'Reilly et al., 1994). Minimal protein was detectable at $23 \mathrm{hr}$, but there was strong expression at $39 \mathrm{hr}$. By the time of maximal expression $(52 \mathrm{hr})$, whether measured by epitope tags or by ligand binding, $>40 \%$ of the cells were permeable to trypan blue. There were no obvious differences in these kinetics between $\mathrm{P} 2 \mathrm{X}_{2}$ and $\mathrm{P} 2 \mathrm{X}_{3}$ receptors. However, there was three- to fourfold less protein expressed by the $\mathrm{P} 2 \mathrm{X}_{3}$-infected cells than the $\mathrm{P} 2 \mathrm{X}_{2}$-infected cells. Coinfection with $\mathrm{P} 2 \mathrm{X}_{2}$ and $\mathrm{P} 2 \mathrm{X}_{3}$ baculovirus also resulted in fewer $\left[{ }^{35} \mathrm{~S}\right] \mathrm{ATP} \gamma \mathrm{S}$ binding sites per cell than expression of $\mathrm{P} 2 \mathrm{X}_{2}$ receptors alone. These differences were also qualitatively apparent in the immunoblots (see Fig. 1).

The binding sites for $\left[{ }^{35} \mathrm{~S}\right] \mathrm{ATP} \gamma \mathrm{S}$ on baculovirus-infected sf 9 cells have the same $K_{\mathrm{D}}(\sim 0.5 \mathrm{nM})$ as those reported in more complete studies by Michel et al. (1996a,b) for P2X $\mathrm{X}_{2}$ receptors expressed by Semliki forest virus in Chinese hamster ovary cells. We observed maximal expression of $\sim 3.3 \times 10^{6}$ binding sites per cell; this corresponds to $\sim 50 \mathrm{pmol} / \mathrm{mg}$ protein (assuming that one 
cell has $1.1 \times 10^{-7} \mathrm{mg}$ of protein), which is approximately twofold larger than the values reported for Semliki forest virus infection by Michel et al. (1996a). [ $\left.{ }^{35} \mathrm{~S}\right] \mathrm{ATP} \gamma \mathrm{S}$ also has been used previously to label ${\mathrm{P} 2 \mathrm{X}_{1}}_{1}$ receptors (Michel et al., 1996b) and $\mathrm{P}_{2} \mathrm{X}_{3}$ receptors (Miller et al., 1996) expressed by Semliki forest virus. The relatively high levels of expression and the ability to follow the receptor by ligand binding may be useful in efforts to purify significant amounts of protein.

The electrophysiological studies on infected insect cells were more difficult on cultures $50 \mathrm{hr}$ after infection because cells were poorly adherent and fragile to gigaseal formation. However, satisfactory recordings were readily made $30 \mathrm{hr}$ after infection, and large (up to $9 \mathrm{nA}$ ) ATP-induced currents were observed. With respect to desensitization of the current during the application and also with respect to the relative effects of ATP and $\alpha \beta$ meATP, these currents closely resembled those observed from other cells infected (Semliki forest virus) or transfected with $\mathrm{P} 2 \mathrm{X}_{2}$ and $\mathrm{P} 2 \mathrm{X}_{3}$ receptors (Evans et al., 1995, 1996). Most strikingly, cells infected with both $\mathrm{P}_{2} \mathrm{X}_{2}$ and $\mathrm{P} 2 \mathrm{X}_{3}$ receptor baculovirus showed the phenotype of a slowly desensitizing response to $\alpha \beta$ meATP, which is not readily accounted for by the independent expression of the two subunits (Lewis et al., 1995).

These electrophysiological results and the more extensive previous work (Lewis et al., 1995) strongly suggest that $\mathrm{P}_{2} \mathrm{X}_{2}$ and $\mathrm{P}_{2} \mathrm{X}_{3}$ subunits can form a new phenotype by heteropolymerization. The immunoprecipitation now demonstrates this directly and shows that the association in the membrane between $\mathrm{P} 2 \mathrm{X}_{2}$ and $\mathrm{P} 2 \mathrm{X}_{3}$ receptor subunits is sufficiently strong to withstand solubilization with $1 \%$ Triton $\mathrm{X}-100$. The method now can be extended to the other members of the P2X receptor family in an effort to determine which subunits can copolymerize when heterologously expressed. Such a direct approach will be particularly useful because many of the possible combinations are not expected to provide any unique phenotype, given the fact that their properties are similar when expressed as single subunits (Collo et al., 1996). On the other hand, they do not address the as yet unsolved question of the actual receptor stoichiometry. Similar experiments on native cells and tissues, using coimmunoprecipitation with antibodies raised against the naturally occurring receptors (Vulchanova et al., 1996; Cook et al., 1997), also will be important in view of the recent evidence that specific combinations may underlie the responses of neurons in defined functional pathways (Cook et al., 1997).

\section{REFERENCES}

Barnard EA (1996) The transmitter-gated channels: a range of receptor types and structures. Trends Pharmacol Sci 17:305-309.

Buell G, Michel AD, Lewis C, Collo G, Humphrey PPA, Surprenant A

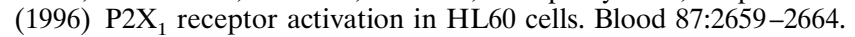

Collo G, North RA, Kawashima E, Merlo-Pich E, Neidhart S, Surprenant A, Buell G (1996) Cloning of $\mathrm{P} 2 \mathrm{X}_{5}$ and $\mathrm{P} 2 \mathrm{X}_{6}$ receptors and the distribution and properties of an extended family of ATP-gated ion channels. J Neurosci 16:2495-2507.

Cook SP, Vulchanova L, Hargreaves KM, Elde RP, McCleskey EW (1997) Distinct P2X receptors mediate ATP actions on nociceptive and non-nociceptive neurons. Nature 387:505-508.

Evans RJ, Lewis C, Buell G, North RA, Surprenant A (1995) Pharmacological characterization of heterologously expressed ATP-gated cation channels ( $\mathrm{P}_{2 \mathrm{X}}$ purinoceptors). Mol Pharmacol 48:178-183.

Evans RJ, Lewis C, Virginio C, Lundstrom K, Buell G, Surprenant A, North RA (1996) Ionic permeability of, and divalent cation effects on, two ATP-gated cation channels ( $\mathrm{P} 2 \mathrm{X}$ receptors) expressed in mammalian cells. J Physiol (Lond) 497:413-422.

Grussenmeyer T, Scheidtmann KH, Hutchinson MA, Eckhart W, Walter G (1985) Complexes of polyoma virus medium $\mathrm{T}$ antigen and cellular proteins. Proc Natl Acad Sci USA 82:7952-7954.

Khakh BS, Humphrey PPA, Surprenant A (1995) Electrophysiological properties of $\mathrm{P}_{2 \mathrm{x}}$ purinoceptors in rat superior cervical, nodose, and guinea pig coeliac neurons. J Physiol (Lond) 484:385-395.

Knudson DL, Tinsley TW (1974) Replication of a nuclear polyhedrosis virus in a continuous cell culture of Spodoptera frugiperda: purification, assay of infectivity, and growth characteristics of the virus. J Virol 14:934-944.

Lewis C, Neidhart S, Holy C, North RA, Buell G, Surprenant A (1995) Coexpression of $\mathrm{P} 2 \mathrm{X}_{2}$ and $\mathrm{P} 2 \mathrm{X}_{3}$ receptor subunits can account for ATP-gated currents in sensory neurons. Nature 377:432-435.

Michel AD, Lundstrom K, Buell GN, Surprenant A, Valera S, Humphrey PPA (1996a) A comparison of the binding characteristics of recombinant $\mathrm{P}_{2} \mathrm{X}_{1}$ and $\mathrm{P} 2 \mathrm{X}_{2}$ purinoceptors. Br J Pharmacol 118:1806-1812.

Michel AD, Lundstrom K, Buell GN, Surprenant A, Valera S, Humphrey PPA (1996b) The binding characteristics of a human bladder recombinant P2X purinoceptor, labelled with $\left[{ }^{3} \mathrm{H}\right] \alpha \beta \operatorname{meATP},\left[{ }^{35} \mathrm{~S}\right] \mathrm{ATP} \gamma \mathrm{S}$, or $\left[{ }^{33} \mathrm{P}\right]-$ ATP. Br J Pharmacol 117:1254-1260.

Miller KJ, Michel AD, Buell G, Lundstrom K, Humphrey PPA (1996) Direct labelling of $\mathrm{P} 2 \mathrm{X}_{3}$ and $\mathrm{P} 2 \mathrm{X}_{4}$ purinoreceptors using $\left[{ }^{35} \mathrm{~S}\right] \mathrm{ATP} \gamma \mathrm{S}$. Br J Pharmacol 118:18P.

Nielsen LK, Smyth GK, Greenfield PF (1991) Hemocytometer cell count distributions: implications of non-Poisson behaviour. Biotechnol Prog 7:560-563.

Nielsen LK, Smyth GK, Greenfield PF (1992) Accuracy of the endpoint assay for virus titration. Cytotechnology 8:231-236.

North RA (1996) Families of ion channels with two hydrophobic segments. Curr Opin Cell Biol 8:474-483.

O'Reilly DR, Miller LK, Luckow VA (1994) An overview of baculoviruses. In: Baculovirus expression vectors: a laboratory manual (O'Reilly DR, Miller LK, Luckow VA, eds), pp 8-10. New York: Freeman.

Surprenant A, Buell G, North RA (1995) $\mathrm{P}_{2 \mathrm{X}}$ receptors bring new structure to ligand-gated ion channels. Trends Neurosci 18:224-229.

Vulchanova L, Arvidsson U, Riedl M, Wang J, Buell G, Surprenant A, North RA, Elde RP (1996) Differential distribution of two ATP-gated ion channels ( $\mathrm{P} 2 \mathrm{X}$ receptors) determined by immunocytochemistry. Proc Natl Acad Sci USA 93:8063-8067.

Whitehorn EA, Tate E, Yanofsky SD, Kochersperger L, Davis A, Mortensen RB, Yonkovich S, Bell K, Dower WJ, Barrett RW (1995) A generic method for expression and use of "tagged" soluble versions of cell surface receptors. Biotechnology 13:1215-1219. 